\title{
Chlorophyllous pigment and lipid stores in the digestive glands of inshore and offshore populations of the deep-sea scallop Placopecten magellanicus
}

\author{
William E. Robinson ${ }^{*}$, Richard W. Langton ${ }^{2}$, Colleen C. Boggs ${ }^{1}$ \\ ${ }^{1}$ New England Aquarium, Harold E. Edgerton Research Laboratory, Central Wharf, Boston, Massachusetts 021 10, USA \\ ${ }^{2}$ Maine Department of Marine Resources, Marine Resources Laboratory, West Boothbay Harbor, Maine 04575, USA
}

\begin{abstract}
Comparably sized deep-sea scallops Placopecten magellanicus from 2 offshore sites in the Gulf of Maine, USA (Fippennies Ledge and Jeffreys Ledge) had significantly lower adductor muscle wet weights, digestive gland wet weights, and digestive gland lipid contents and concentrations than scallops collected from a coastal site in Maine (Ram Island). Scallops transplanted from Ram Island to Fippennies Ledge for 1 yr showed no differences from the indigenous Fippennies Ledge scallops in mean adductor wet weights, digestive gland wet weights, lipid contents and concentrations, or the contents and concentrations of chlorophyllous pigments stored in the digestive gland. Pigment analysis of stomach and intestinal contents, while reflecting recent ingestion, did not display a consistent pattern from one year to the next, and was therefore of little value for comparing nutritional histories between scallop populations. Phaeophorbide a was the primary breakdown product of chlorophyll $a$, identified in acetone extracts of stomach contents, intestinal material, and digestive gland tissues by reverse phase high performance liquid chromatography (RP-HPLC). Low concentrations of chlorophyll $a_{1}$ phaeophytin $a$, chlorophyllide $a$ and phaeophorbide $c$ were also identified in digestive gland and ingested material extracts using HPLC. Numerous unidentified chromatographic peaks were present as well. The absorption and storage of chlorophyllous pigments in digestive gland tissues mimicked the pattern of abundance measured in the stomach and intestinal contents. Offshore scallops collected in 1986 and 1987 stored more phaeopigments in digestive gland tissues than inshore scallops. Digestive gland phaeopigment concentrations varied independently of both lipid stores and digestive gland wet weights, and were therefore poor indices of long-term nutritional history. Lipid content, however, was directly correlated with digestive gland wet weight.
\end{abstract}

\section{INTRODUCTION}

The autofluorescence of chlorophylls and their breakdown products, phaeopigments, have been used as natural markers to investigate feeding and digestion in a number of marine invertebrates. In most cases, fluorescence analysis has concentrated on gut contents and feces. For example, feeding patterns and diurnal vertical migrations of copepods and mysids have been inferred from the analyses of acetone extracts of gut contents and feces (Mackas \& Bohrer 1976, Grossnickle 1979, Baars \& Oosterhuis 1984, Head et al. 1984, Mackas \& Burns 1986, Ohman 1988). Fluorescence meas-

\footnotetext{
- Addressee for correspondence
}

urements have been used to calculate either filtration, grazing or ingestion rates in copepods (Adams \& Steele 1966, Dagg 1983, Wang \& Conover 1986), salps (Madin \& Cetta 1984) and bivalves (Bricelj \& Malouf 1984, Hummel 1985). Algal ingestion and digestion have been directly monitored by epifluorescence microscopy for bivalve veligers fed either unialgal suspensions (Babinchak \& Ukeles 1979, Le Pennec \& RangelDavalos 1985) or mixtures of algae and inert suspended matexial (Robinson 1983). Pigment analysis has been employed to measure differences in either digestive or absorption efficiencies in adult bivalves feeding on mixtures of algae and suspended sediments (Robinson et al. 1984, Hawkins et al. 1986).

Several workers attempted to relate the concen- 
trations of chlorophyllous pigments extracted from various bivalve tissues with the long-term feeding history (months, seasons, etc.) of the animals. Ansell (1974a,b) concluded that the seasonal fluctuations of phaeopigment in either the whole body tissues of Abra alba or the 'mantle' (defined as the remaining viscera after removal of gonad and adductor muscle) of Chlamys septemradiata corresponded to variations in feeding activity. He further concluded that the main site of chlorophyllous pigment storage was in the bivalve digestive gland. Subsequent studies have demonstrated that these pigments are predominantly phaeopigments and are primarily located in the lipid droplets stored in the intracellular vacuoles of the digestive gland's absorbing cells (Gelder \& Robinson 1980). It is therefore likely that stored phaeopigment concentrations would co-vary with lipid concentrations in the digestive gland tissue, and could be used as an index of nutritional state. Mann (1977), however, cautioned against the use of pigment analyses of whole body acetone extracts as a relative measure of nutritional state, since the contribution from gut contents may change markedly over a short time period (days or weeks) due to the patchiness of food resources. It is clear that pigments present in the gut contents must be separated from those stored within the tissues per se in any assessment of long-term nutritional state

The present study was designed to evaluate the hypothesis that concentrations of chlorophyllous pigments stored in the digestive gland of a bivalve mollusc can be used as a relative index of nutritional state. A comparison of offshore $1>45 \mathrm{~km}$ from landfall, $>60 \mathrm{~m}$ depth) vs inshore (within $1 \mathrm{~km}$ of mainland, $<25 \mathrm{~m}$ depth) populations of the deep-sea scallop Placopecten magellanicus (Gmelin, 1791) was chosen to test the hypothesis, since these populations are subjected to different physical environments, and potential concentrations and types of algal food (Townsend \& Spinrad 1986. Shumway et al. 1987). Separate analyses were conducted on both stomach and intestinal contents in addition to digestive gland tissue in order to factor out short-term nutritional state (as potentially indicated by gut contents and effected by short-term fluctuations in food supply) from long-term feeding history (as may be reflected in pigment stores).

\section{MATERIALS AND METHODS}

Placopecten magellanicus were collected from an inshore population near Ram Island, Boothbay Harbor, Maine, USA $\left(43^{\circ} 48.09^{\prime} \mathrm{N}, 69^{\circ} 35.58^{\prime} \mathrm{W} ; 10\right.$ to $25 \mathrm{~m}$ depth; ca 8 to $12^{\circ} \mathrm{C}$ ) by SCUBA divers on 26 June 1986 and 24 June 1987 . Scallops were transported by boat, immersed in seawater, back to the Maine Department of Marine Resources laboratory in W Boothbay for processing. An additional sample of scallops was collected from the Ram Island population in 1986, fitted with numbered 'spaghetti' tags, maintained in running seawater and transplanted to an offshore site on Fippennies Ledge in the Gulf of Maine $\left(42^{\circ} 44.47^{\prime} \mathrm{N}\right.$, $69^{\circ} 17.10^{\prime} \mathrm{W} ; 75 \mathrm{~m}$ depth; $5^{\circ} \mathrm{C}$ ) $5 \mathrm{~d}$ after collection

Scallops were collected from 2 offshore populations in the Gulf of Maine in 1986: Fippennies Ledge $\left(42^{\circ} 44.47^{\prime} \mathrm{N}, 69^{\circ} 17.10^{\prime} \mathrm{W} ; 87\right.$ to $110 \mathrm{~m}$ depthi $5^{\circ} \mathrm{C}_{i}$ $1 \mathrm{July}) ;$ and Jeffreys Ledge $\left(42^{\circ} 52.12^{\prime} \mathrm{N}, 70^{\circ} 08.48^{\prime} \mathrm{W}\right.$; 63 to $65 \mathrm{~m}$ depth; $5^{\circ} \mathrm{C} ; 3$ and 4 July). The same Fippennies Ledge site was resampled on 26 June 1987, and the scallops that were transplanted from Ram Island in 1986 were recovered on 27 to 29 June 1987. All scallop collections from the offshore sites, as well as the deployment and retrieval of the transplanted scallops, were made using the manned submersible 'Delta' (Marfab Systems, Inc.). Scallops were processed immediately upon return to the ship.

Following measurement of shell height (mm), scallops were dissected and tissues separated into adductor muscle, digestive gland (including stomach) and remaining viscera. Adductor and viscera were frozen $\left(-20^{\circ} \mathrm{C}\right)$ for subsequent wet-weighing in the laboratory.

The digestive gland and stomach of each scallop was cut open and the contents flushed out and collected under vacuum on a tared Gelman GN-6 cellulose acetate filter $(0.45 \mu \mathrm{m})$. Filters were rinsed with 50 to $100 \mathrm{ml}$ of $1.3 \mathrm{M}$ ammonium formate to remove salts, and stored in individual containers at $-20^{\circ} \mathrm{C}$ for later processing, In individuals where the stomach was packed with material (most often the case for the Ram Island scallops), only enough was collected to permit vacuum filtration within a reasonable time $(<30 \mathrm{~min})$. Fecal material was squeezed from the hindgut and rectum, collected on a tared $0.45 \mu \mathrm{m}$ cellulose acetate filter, washed with $1.3 \mathrm{M}$ ammonium formate and stored at $-20^{\circ} \mathrm{C}$. After thoroughly flushing the stomach and primary ducts of the digestive gland with ammonium formate solution, the digestive gland was cut into 3 parts (one for pigment analysis, one for lipid analysis, one as a backup). Each piece was stored in an individual tared scintillation vial at $-20^{\circ} \mathrm{C}$ for the duration of the cruise. Once back in the laboratory, each of the frozen stomach and intestinal content filters, digestive gland vials, adductor muscles and remaining viscera was weighed.

Stomach contents, feces and pieces of digestive gland were analyzed for chlorophyll $a$ and phaeopigments using standard fluorometric procedures (HolmHansen et al. 1965, Strickland \& Parsons 1972). Digestive gland tissue and filters with stomach and intestinal contents were extracted in $10 \mathrm{ml}$ of $90 \%$ acetone 
(analytical grade) containing ca $1 \mathrm{mg}$ of magnesium carbonate for a minimum of $24 \mathrm{~h}$, in the dark, at $-24^{\circ} \mathrm{C}$. Following centrifugation of each sample, stomach and intestinal samples were readjusted to $10.0 \mathrm{ml}$ and digestive gland samples brought up to $25.0 \mathrm{ml}$ with $90 \%$ acetone. Measurements were then made on a Turner model 111 fluorometer equipped with a Corning CS-5-60 excitation filter, Corning CS-2-60 emission filter and standard photomultiplier tube with S-4 photocathode. Chlorophyll $a$ and phaeopigment concentrations were calculated based on standard curves of chlorophyll a (Sigma C6144) in $90 \%$ acetone for each fluorometer door setting, an empirically determined acid factor for pure chlorophyll a (10x scale, $1.63 ; 3 \times$ scale, 1.70 ), and the equations presented by Strickland \& Parsons (1972). Blanks consisted of $90 \%$ acetone containing a cellulose acetate filter (stomach and intestinal contents) or $90 \%$ acetone alone (digestive gland samples). All phaeopigment concentrations are reported as equivalent weights of chlorophyll a (Conover et al. 1986).

In addition to the standard fluorometric analyses, stomach, feces and digestive gland samples from half of the scallops collected in 1987 were re-analyzed using reverse-phase high performance liquid chromatography (RP-HPLC), according to the methodology of Mantoura \& Llewellyn (1983). Two ml of each $90 \%$ acetone extract was combined with $0.6 \mathrm{ml}$ of ion-pairing solution ( $1.5 \mathrm{~g}$ tetrabutylammonium acetate plus $7.7 \mathrm{~g}$ ammonium acetate made up to $100 \mathrm{ml}$ with distilled water) and incubated at $-24^{\circ} \mathrm{C}$ in the dark for a minimum of $12 \mathrm{~h}$ prior to chromatography. Samples (50 to $200 \mu \mathrm{l}$ ) were analyzed on a dual pump Waters 6000A HPLC, equipped with a U6K injector, and a Turner model 111 fluorometer $(100 \mu$ quartz. flow-through cell, RCA 4840 red sensitive photomultiplier, mercury-arc lamp, Corning CS-5-60 excitation filter and Corning CS-2-64 emission filter). Separations were achieved on a Shandon $5 \mu \mathrm{m}$ Hypersil ODS $250 \times$ $4.6 \mathrm{~mm} \mathrm{RP}$ column, at a flow rate of $1.5 \mathrm{ml} \mathrm{min} \mathrm{m}^{-1}$ (3000 to 3500 psi), using linear gradient elution. The separation was started with an initial mobile phase of $1: 1: 8$ ion-pairing solution: distilled water: methanol and proceeded to $1: 4$ acetone : methanol in $10 \mathrm{~min}$, followed by isocratic hold for $23 \mathrm{~min}$. Calibration was accomplished using a chlorophyll a (Sigma C6144) dilution series (90\% acetone with ion-pairing reagent). Detection limit for chlorophyll a was $0.12 \mathrm{ng}$. Phaeophytin a was obtained using the methodology of Mantoura \& Llewellyn (1983) and epimerized chlorophyll a according to Zapata et al. (1987). Other chromatographic peaks were identified by comparison with peaks from diatom and green algal extracts in conjunction with their reported rf values from Mantoura \& Llewellyn (1983). Phaeopigment concentrations were not calibrated by
HPLC due to the unavailability of purified standards. Although samples were chromatographed as soon after initial extraction as possible, some epimerization of chlorophyll $a$ and phaeophytin a was expected during storage (Watanabe et al. 1986, 1987), although little chlorophyll a degradation should have ensued (Hains 1985, Wang \& Conover 1986). Total chlorophyll a was therefore calculated as the sum of chlorophyll $a$ and $a^{\prime}$.

Since phaeopigments are primarily stored in digestive gland lipid droplets (Gelder \& Robinson 1980), digestive gland lipid content was measured in order to normalize phaeopigment content to lipid content as well as to digestive gland wet weight. In addition, total lipid content of the digestive gland provides a relative index of nutritional state which varies in tandem with the seasonal changes in carbohydrate content of the sea scallop's adductor muscle (Robinson et al. 1981). Total lipid extraction was conducted on 0.4 to $1.5 \mathrm{~g}$ subsamples of digestive gland tissue following the procedure of Bligh \& Dyer (1959). Two to three extractions were made on each tissue piece. Triplicate aliquots of each extract were dried at $55^{\circ} \mathrm{C}$ prior to weighing.

\section{RESULTS}

No attempt was made to collect a uniform size range of scallops, due primarily to the time restraints imposed by submersible collecting. Nevertheless, mean shell heights, as well as the mean wet weights of the remaining viscera (exclusive of digestive gland and adductor muscle), were similar for each group of scallops collected in a particular year (Table 1). Placopecten magellanicus collected in 1987 tended to be larger than those collected in 1986 (mean shell height 118 to $124 \mathrm{~mm}$ vs 105 to $108 \mathrm{~mm}$. Although it is tempting to surmise that this difference reflects the annual growth of scallops in each population, sample sizes were too small to either support or refute this conclusion. $\mathrm{Nu}$ merical comparisons throughout this paper should, therefore, be limited to within-year data, although trends can be compared both within and between years.

Although mean shell height and mean weight of remaining viscera were similar for each of the sampled groups within the same year, both mean adductor and mean digestive gland wet weights were significantly lower for offshore scallops compared to Ram Island scallops (Table 1; ANOVA, $p<0.05$ ). Similarly, both the amount and concentration of lipid in the digestive gland of offshore scallops was significantly lower than for the inshore population (Table 1; ANOVA, $p<0.05$ ). No differences were observed between mean adductor and digestive gland weights, mean lipid content and concentrations between the Fippennies Ledge and 
Table 1 Placopecten magellanicus. Height, wet weight and lipid content comparisons $(\bar{X} \pm S D ; n=15$ scallops for 1986,10 for 1987 ). ${ }^{+}$or $*$ denotes mean values significantly different from Ram Island for the same collection year (ANOVA, Duncan a posteriori contrast, $p<0.05$ )

\begin{tabular}{|c|c|c|c|c|c|c|}
\hline & Ram Island & $\begin{array}{l}1986 \\
\text { Fippennies } \\
\text { Ledge }\end{array}$ & $\begin{array}{l}\text { Jeffreys } \\
\text { Ledge }\end{array}$ & Ram Island & $\begin{array}{l}1987 \\
\text { Fippennies } \\
\text { Ledge }\end{array}$ & $\begin{array}{l}\text { Fippennies } \\
\text { Transplants }\end{array}$ \\
\hline Shell ht (mm) & $108.5 \pm 16.2$ & $105.3 \pm 18.2$ & $107.4 \pm 7.8$ & $118.2 \pm 12.2$ & $123.6 \pm 6.2$ & $123.8 \pm 11.7$ \\
\hline $\begin{array}{l}\text { Remaining viscera } \\
\text { wet wt }(\mathrm{g})\end{array}$ & $33.6 \pm 19.5$ & $21.9 \pm 10.8$ & $24.1 \pm 5.6$ & $46.0 \pm 17.1$ & $36.1 \pm 8.8$ & $37.9 \pm 10.6$ \\
\hline Adductor wet wt $(g)$ & $23.0 \pm 10.2$ & $12.6^{+} \pm 5.7$ & $16.1^{+} \pm 3.7$ & $31.1 \pm 9.9$ & $20.0 * \pm 5.5$ & $20.9^{*} \pm 6.4$ \\
\hline $\begin{array}{l}\text { Digestive gland wet } \\
\text { wt }(g)\end{array}$ & $5.1 \pm 2.0$ & $3.0^{+} \pm 1.3$ & $3.6^{+} \pm 0.7$ & $6.2 \pm 1.8$ & $4.4^{*} \pm 0.7$ & $3.8 \div \pm 1.2$ \\
\hline $\begin{array}{l}\text { g lipid/digestive } \\
\text { gland }\end{array}$ & $0.528 \pm 0.272$ & $0.151^{+} \pm 0.090$ & $0.247^{+} \pm 0.078$ & $0.572 \pm 0.162$ & $0.176^{*} \pm 0.076$ & $0.168 * \pm 0.105$ \\
\hline $\begin{array}{l}g \text { lipid/g digestive } \\
\text { gland wet wt }\end{array}$ & $0.103 \pm 0.040$ & $0.051 * \pm 0.020$ & $0.069^{+} \pm 0.017$ & $0.094 \pm 0.012$ & $0.040^{*} \pm 0.013$ & $0.042^{2 *} \pm 0.015$ \\
\hline
\end{tabular}

Jeffreys Ledge scallop collections in 1986, or between the indigenous scallops and transplanted scallops sampled from Fippennies Ledge in 1987.

Short-term feeding histories, as reflected in pigment analysis of stomach and intestinal contents, are highly variable between individual scallops collected from each site (Table 2). The amount of material sampled does not reflect the total amount of stomach contents or feces. Ram Island scallops, for example, tended to have much more material in their stomachs in both years than the offshore scallops. In 1986. Fippennies Ledge scallops had noticeably less material in their stomachs than either the Jeffreys Ledge or Ram Island scallops.

Mean concentrations of chlorophyll a (as determined fluorometrically) in both stomach and intestinal contents were far more variable than phaeopigment concentrations (stomach chl a coefficient of variation (CV) 65 to $234 \%$, phaeo CV 25 to $58 \%$; intestinal chl a CV 126 to $300 \%$, phaeo CV 34 to $126 \%$ ). Overall, between
10 and $50 \%$ of all the Ram Island scallops collected had no chlorophyll a in their stomach or intestinal contents. In contrast, 15 to $80 \%$ of the offshore scallops, taken together, lacked chlorophyll a. When present, chlorophyll a concentrations were always measured close to the detection limits of the fluorometric technique $(0.1 \mu \mathrm{g}$ chl a) and were overshadowed 1 to 2 orders of magnitude by phaeopigment concentrations. Because of the difficulty of measuring low concentrations of chlorophyll $a$ in the presence of high phaeopigment concentrations (Holm-Hansen et al. 1965, Trees et al. 1985), the chlorophyll a measurements, as determined fluorometrically, should be interpreted with caution.

Phaeopigments were measured using the fluorometric technique in all stomach and intestinal content samples at levels well above the detection limit. In 1986 , no differences in phaeopigment concentrations were observed for the feces from offshore and Ram Island

Table 2. Placopecten magellanicus. Stomach and intestinal contents. Mean ( \pm SD) amount of material sampled, and chlorophyll and phaeopigment concentrations in that material. Sample size $=15$ scallops for 1986,10 for $1987+$ or $*$ denotes mean values significantly different from Ram Island for the same collection year (ANOVA, Duncan a posteriori contrast, $p<0.05$ )

\begin{tabular}{|c|c|c|c|c|c|c|}
\hline & \multicolumn{3}{|c|}{1986} & \multicolumn{3}{|c|}{1987} \\
\hline & Ram Island & $\begin{array}{c}\text { Fippennies } \\
\text { Ledge }\end{array}$ & $\begin{array}{l}\text { Jeffreys } \\
\text { Ledge }\end{array}$ & Ram Island & $\begin{array}{l}\text { Fippennies } \\
\text { Ledge }\end{array}$ & $\begin{array}{l}\text { Fippennies } \\
\text { Transplants }\end{array}$ \\
\hline Stomach contents & & & & & & \\
\hline $\begin{array}{l}\text { Amount of material } \\
\text { (g wet } w t)\end{array}$ & $0.41 \pm 0.26$ & $0.19^{+} \pm 0.13$ & $0.36 \pm 0.13$ & $0.33 \pm 0.15$ & $0.28 \pm 0.02$ & $0.25 \pm 0.08$ \\
\hline$\mu \mathrm{g} c h l a / g$ wet wt & $0.63 \pm 1.14$ & $1.48 \pm 1.14$ & $0.10^{+} \pm 0.12$ & $2.66 \pm 1.73$ & $0.29^{*} \pm 0.68$ & $0.30 * \pm 0.39$ \\
\hline$\mu \mathrm{g}$ phaeo/g wet wt & $32.47 \pm 17.39$ & $39.92 \pm 22.39$ & $16.58^{+} \pm 4.11$ & $52.12 \pm 19.38$ & $28.59^{*} \pm 7.94$ & $36.31^{*} \pm 21.12$ \\
\hline $\begin{array}{l}\text { Intestinal contents } \\
\text { Amount of material } \\
\text { (g wet wt) }\end{array}$ & $0.21 \pm 0.06$ & $0.12^{+} \pm 0.07$ & $0.24 \pm 0.02$ & $0.17 \pm 0.02$ & $0.26^{*} \pm 0.02$ & $0.27^{*} \pm 0.03$ \\
\hline$\mu \mathrm{g} \mathrm{chl} a / g$ wet wt & $1.55 \pm 2.20$ & $1.52 \pm 3.61$ & $1.29 \pm 1.63$ & $0.80 \pm 1.07$ & $0.04 * \pm 0.12$ & $0.10 \pm 0.25$ \\
\hline ug phaeo/g wet wt & $50.99 \pm 47.67$ & $37.79 \pm 47.56$ & $23.17 \pm 12.88$ & $58.91 \pm 19.90$ & $19.94 * \pm 10.92$ & $21.15^{*} \pm 11.12$ \\
\hline
\end{tabular}


scallops, although the stomach contents of Jeffreys Ledge scallops had significantly less phaeopigment than either the Fippennies Ledge or Ram Island scallops. In 1987 on the other hand, phaeopigment concentrations in both the stomach and intestinal contents were significantly less in the offshore than in the Ram Island scallops, regardless of the amount of material collected from either the stomach or intestine. Short-term feeding patterns are highly variable, although phaeopigment concentrations in the stomach contents of offshore scallops are either similar to or lower than concentrations from inshore scallops. Intestinal contents of offshore scallops tend to have lower concentrations of phaeopigments than inshore scallops.

Variable amounts of chlorophyll $a$ were measured in scallop digestive glands using the fluorometric technique (Fig. 1A, B). No chlorophyll a was detected in 60 to $80 \%$ of the scallops collected from Ram Island, nor in 50 to $90 \%$ of the scallops collected offshore. Due in part to this extreme variability, no differences were measured in either mean chlorophyll a content or mean concentration in groups sampled in 1987 (ANOVA, $p>0.05$ ). In 1986, the total amount of digestive gland chlorophyll a was lower in Ram Island scallops compared to the 2 offshore sites, although chlorophyll a concentrations were similar. As was the case with the stomach and intestinal content chlorophyll a measure- ments, concentrations in the digestive gland were over an order of magnitude below the measured phaeopigment concentrations. The reported chlorophyll a values should therefore be interpreted cautiously.

In contrast to the short-term pattern of phaeopigments observed in the stomach contents and feces, higher amounts, and concentrations, of stored phaeopigments were found in digestive glands of offshore, rather than inshore, scallops (Fig. 1C, D, E; ANOVA, $p<0.05$ ). This distinct trend was evident in both years. Phaeopigment concentrations were significantly higher in all offshore scallop digestive glands regardless of whether pigments were normalized on the basis of wet tissue weight (Fig. 1D) or lipid content (Fig. 1E).

The amount of stored phaeopigments did not correlate with either digestive gland wet weight or with the amount of lipid extracted from the gland, in either year (Fig. 2A to D). However, the sets of data points from each sample site formed a distinct cluster in each of the graphs. These patterns changed to some extent from one year to the next. Ram Island scallops, for example, tended to have higher digestive gland wet weights and lipid contents, although lower amounts of phaeopigment than the offshore scallops. These inshore scallops showed much greater interanimal variability in all measured parameters than offshore scallops. A difference in the pattern of clustering can be clearly seen
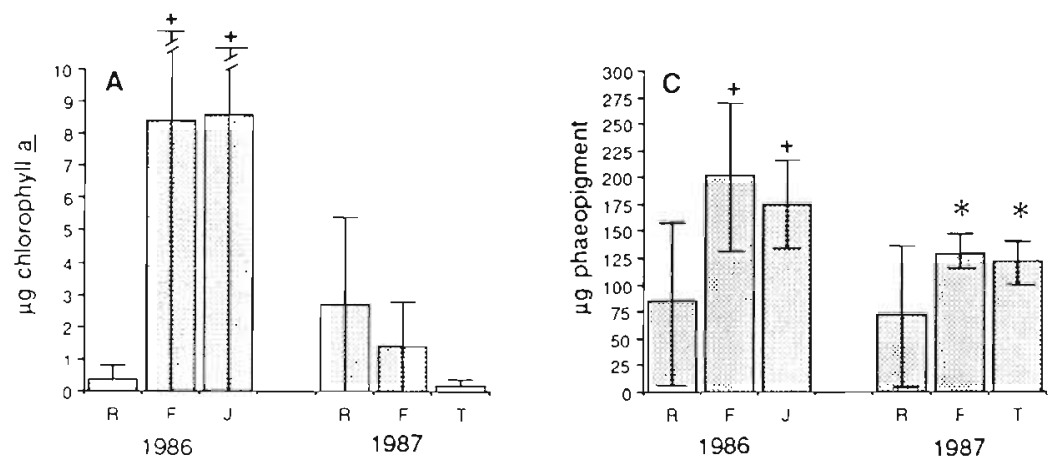

$R=$ Ram Island

$\mathrm{F}=$ Fippennies Ledge
$\mathrm{J}=$ Jeftreys Ledge
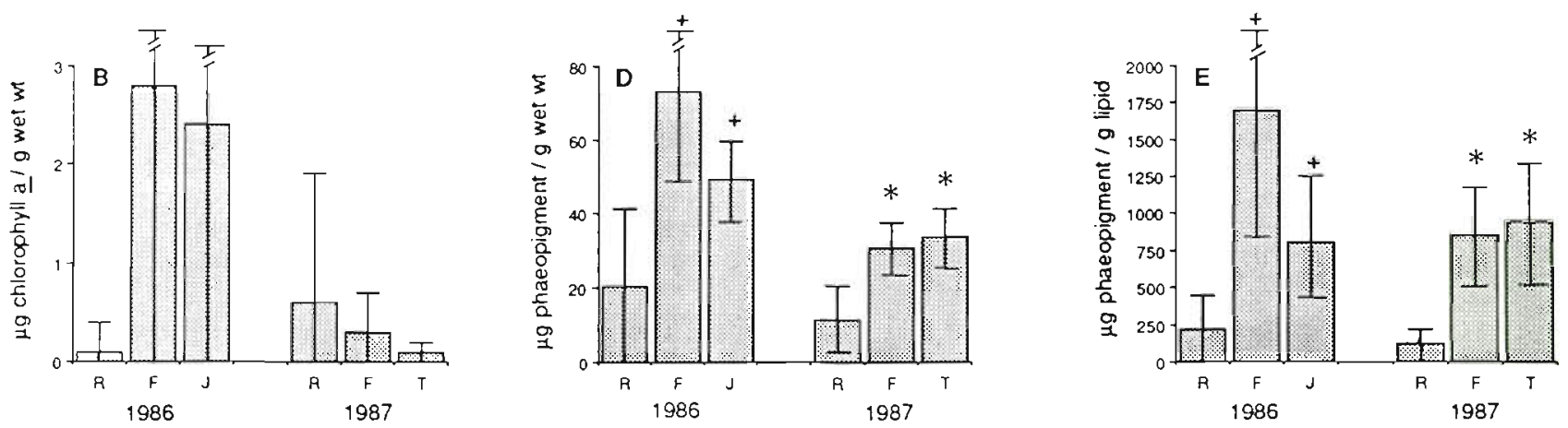

Fig. 1. Placopecten magellanicus. ( $A, C)$ Mean content and ( $B, D, E)$ concentration of chlorophyll a and phaeopigments stored in the digestive gland, as determined fluorometrically. Error bars: $\pm 1 \mathrm{SD} ; n=15$ for 1986 samples, 10 for 1987 . + or $*$ denotes mean values significantly different from Ram Island for the same collection year (ANOVA, Duncan a posteriori contrast, $p<0.05$ ). $\mathrm{R}$ :

Ram Island; F: Fippennies Ledge; J: Jeffreys Ledge; T: Ram Island scallops transplanted to Fippennies Ledge for 1 yr 

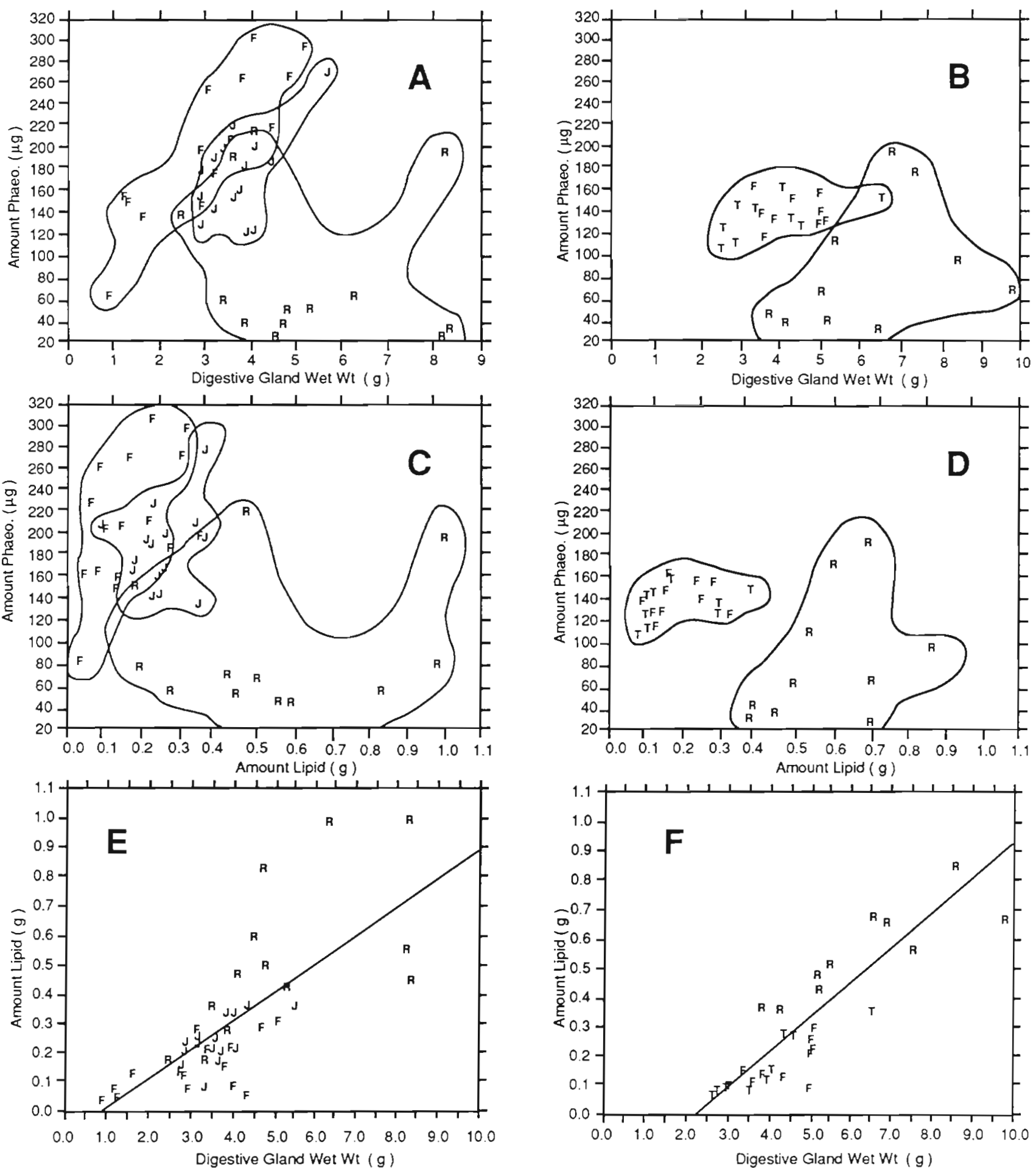

Fig. 2. Placopecten magellanicus. Relationship between amount of digestive gland phaeopigment (ug), digestive gland wet weight $(g)$ and amount of digestive gland lipid $(g)$ for $(A, C, E)$ scallops sampled in 1986 and $(B, D, F) 1987$. Contours fit by eye. R:

Ram Island; F: Fippennies Ledge; J. Jeffreys Ledge; T. Ram Island scallops transplanted to Fippennies Ledge for 1 yr

between the Jeffreys Ledge and Fippennies Ledge scallops, with much greater variability in phaeopigment content observed in the 1986 Fippennies Ledge scallops. Scallops transplanted from Ram Island to Fippennies Ledge for 1 yr displayed an identical pattern to that of the Fippennies Ledge indigenous scallops. 
There is a significant correlation between the amount of lipid extracted from a digestive gland and the wet weight of the gland (Fig. 2E, F). Linear regressions for each of the yearly samples are not significantly different (ANOVA, $p<0.05 ; 1986, y=0.10 x-0.09, n=45$ $r^{2}=0.51 ;$ 1987, $\left.y=0.12 x-0.25, n=30, r^{2}=0.75\right)$ Variability around each regression line increases with increasing digestive gland weight or lipid content.

HPLC analysis of the stored digestive gland chlorophyllous pigments reveals a very complex chromatogram (compare Fig. 3A with the extract of Skeletonema costatum from a stationary phase culture in Fig. 3D). The numerous unknown chromatographic peaks could represent either unidentified chlorophyll degradation products or fluorescing compounds metabolically produced by the scallop itself. No appreciable differences were seen in chromatograms of inshore vs offshore scallops, or between chromatograms of stored digestive gland pigments and those present in stomach and intestinal contents. Similar identifiable and unidentifiable chromatographic peaks were present in digestive gland, stomach content and fecal samples. Of the identified peaks, phaeophorbide $a$ was present at higher concentrations than either chlorophyll $a$, phaeophytin a or chlorophyllide $a$ in stomach contents, feces and digestive gland tissue.
Only 1 to 2 unidentifiable peaks exceeded the peak heights for phaeophorbide $a$. Chlorophyll $b$ and its degradation products were never found in digestive gland tissue, stomach or intestinal contents of either offshore or inshore scallops. Chlorophyll $c$, on the other hand, was detected in all groups of scallops.

Due to the enhanced analytical sensitivity of HPLC, low concentrations of intact chlorophyll a were identified in all but one of the 15 digestive gland tissue samples (1987 cruise; Table 3). Chlorophyll a was measured in only 5 of the same samples by fluorometric analysis. Chlorophyll a was also identified by HPLC in 14 of the 15 stomach content samples and 12 of the 15 fecal samples. Ratios of intestinal to stomach content chlorophyll a concentrations (I/S ratio, based on HPLC data; Table 3) were higher for the Ram Island scallops (range 0.5 to 3.8) than for the scallops collected offshore (range $<0.02$ to 2.1 ). No difference in the I/S ratio was observed between the indigenous Fippennies Ledge scallops (range $<0.2$ to 1.2 ) and the recovered transplants (range $<0.02$ to 2.1 ). In contrast, the ratio of digestive gland: stomach content chlorophyll a (DG/S ratio) tended to be lower for the Ram Island scallops than for the Fippennies Ledge indigenous scallops, reflecting the lower concentrations of stored chlorophyllous pigments in the inshore scallops.
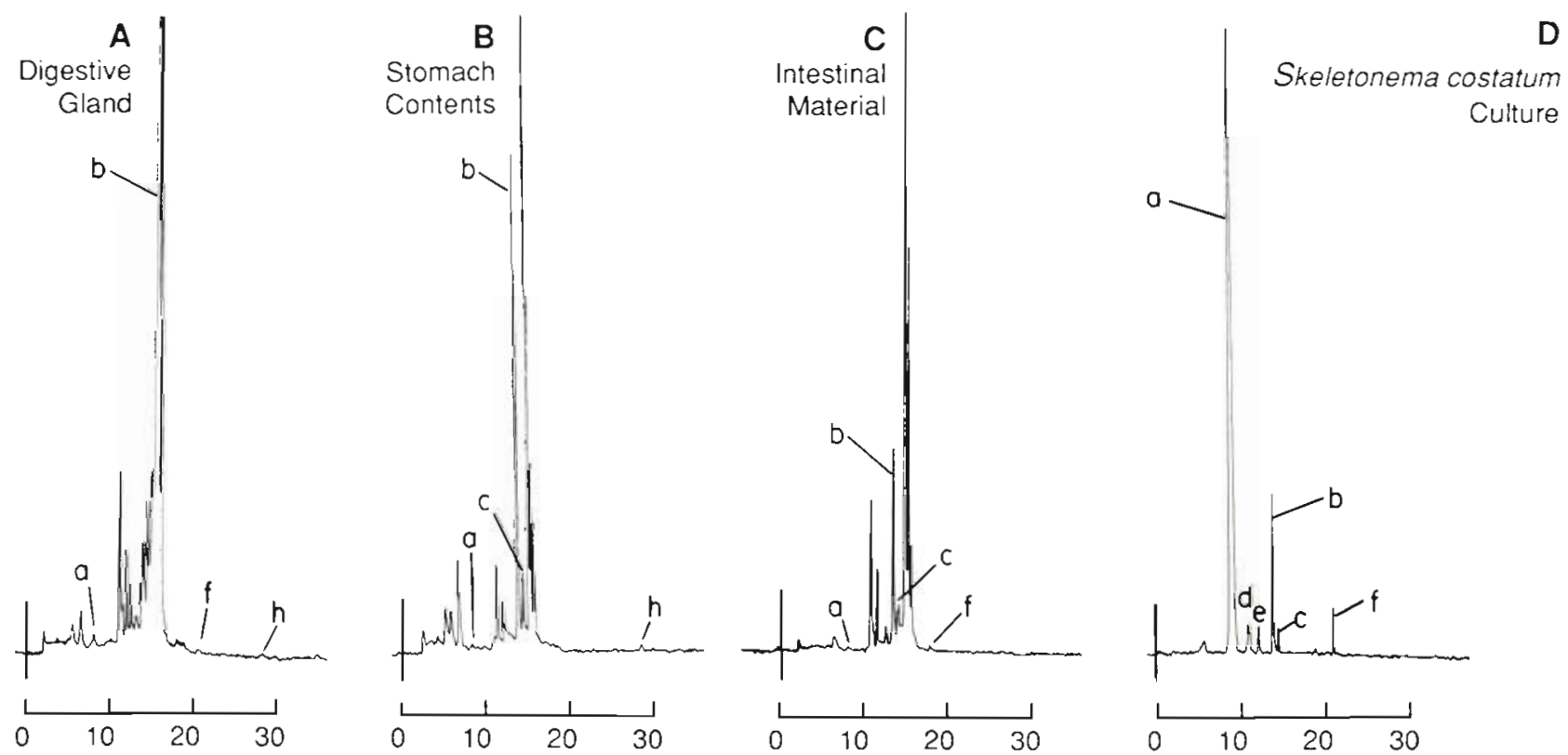

$m$ i $n$ u t e s

Fig. 3. Placopecten magellanicus. RP-HPLC chromatograms of $90 \%$ acetone extracts of (A) digestive gland tissue ( $40 \mu \mathrm{l}$ injection), (B) stomach contents $(50 \mu \mathrm{l}$ injection) and (C) intestinal material $(200 \mu \mathrm{l}$ injection) from a Ram Island scallop (\#23). Pigment chromatogram for the diatom Skeletonema costatum (stationary phase culture) is presented for comparison. Peaks are identified as: $a$, chlorophyllide $a ; b$, phaeophorbide $a ; c$, phaeophorbide $c ; d$, chlorophyll $c$; e, methyl chlorophyllide a ester; $f$, chlorophyll $a$; h, phaeophytin a. Identification of peaks is based on a comparison of if values of standard solutions (chlorophyll a and a', phaeophytin a) or comparison with published rf values and pure algal culture extracts (all other compounds) 
Table 3. Placopecten magellanicus. Chlorophyll a concentrations (ng per g wet wt) in digestive gland tissue, stomach and intestinal contents determined by HPLC. I/S ratio: intestine/stomach chlorophyll a ratio; DG/S: digestive gland/stomach chlorophyll a ratio; Ram: Ram Island; Fip: Fippennies Ledge; Trans: Ram Island scallops transplanted to Fippennies Ledge for 1 yr

\begin{tabular}{|c|c|c|c|c|c|}
\hline \multirow[t]{2}{*}{ Sample \# } & \multicolumn{3}{|c|}{ Chl a (ng g $\left.g^{-1}\right)^{a}$} & \multirow[t]{2}{*}{$\mathrm{I} / \mathrm{S}$ ratio } & \multirow[t]{2}{*}{ DG/S ratio } \\
\hline & Digestive gland & Stomach & Intestine & & \\
\hline $\operatorname{Ram} 22$ & 625.9 & 651.8 & 335.8 & 0.52 & 0.96 \\
\hline $\operatorname{Ram} 23$ & 148.8 & 208.7 & 132.7 & 0.64 & 0.71 \\
\hline Ram 24 & 195.1 & 64.5 & 243.6 & 3.78 & 3.00 \\
\hline $\operatorname{Ram} 26$ & 127.7 & 523.9 & 929.0 & 1.77 & 0.24 \\
\hline Ram 30 & 177.2 & 329.9 & 384.4 & 1.16 & 0.54 \\
\hline Fip 21 & 266.9 & 174.0 & 71.7 & 0.41 & 1.50 \\
\hline Fip 23 & 258.9 & 93.0 & $<18.5$ & $<0.20$ & 2.80 \\
\hline Fip 24 & 180.7 & $<14.8$ & $<16.4$ & - & $>12.00$ \\
\hline Fip 25 & $<40.9$ & 103.4 & 102.8 & 0.99 & $<0.40$ \\
\hline Fip 30 & 283.5 & 115.7 & 141.7 & 1.22 & 2.50 \\
\hline Trans 1 & 308.5 & 823.6 & $<18.1$ & $<0.02$ & 0.37 \\
\hline Trans 5 & 275.4 & 275.5 & 102.5 & 0.37 & 1.00 \\
\hline Trans 6 & 261.1 & 136.5 & 92.4 & 0.68 & 2.00 \\
\hline Trans 8 & 101.5 & 145.5 & 301.8 & 2.08 & 0.70 \\
\hline Trans 10 & 370.2 & 549.8 & 255.7 & 0.46 & 0.66 \\
\hline
\end{tabular}

The chromatograms of chlorophyllous pigments were quite similar for the digestive gland tissue, stomach contents and feces extracts (Fig. 3A to C). The same identified and unidentified chromatographic peaks were found in extracts of all 3 materials. There was no indication that any one of the identified pigments or group of pigments was absorbed and stored in digestive cells in preference to any other. Once algal food was digested extracellularly in the stomach, each of the degradation products was apparently absorbed in proportion to its amount in the stomach. There was no evidence that additional degradation occurred in the digestive gland on either intact chlorophylls or their initial degradation products.

\section{DISCUSSION}

The higher concentrations of lipid as well as the larger size of the digestive gland in Ram Island scallops as compared to those from either Fippennies Ledge or Jeffreys Ledge supports the general contention that inshore scallops have greater nutritional reserves and potential for somatic growth and reproduction than offshore scallop populations (Barber et al. 1988, Schick et al. in press). Gonadal and somatic production are reduced in deep water scallops from Canadian waters where temperature is lower and food conditions poorer than for shallow water populations (MacDonald \& Thompson 1985). Similarly, gonadal output, reproductive effort and residual reproductive value are less for deep water scallops (MacDonald et al. 1987).
It is puzzling therefore that phaeopigment levels are greater in the digestive glands of offshore scallops. Previously these lipid-soluble degradation products of chlorophyll have been shown to be primarily localized in lipid droplets within the digestive cells of the bivalve digestive gland (Gelder \& Robinson 1980) although some phaeopigment is also present in the cytosol of these cells. Because of the lipophilic nature of these pigments, it is logical to assume that lipid and phaeopigment stores would co-vary. In contrast, the present study strongly suggests that the storage and/or metabolism of phaeopigments occur at different rates than for lipid. The differences observed between inshore and offshore scallops probably reflect geographic differences in not only the amount of these 2 groups of organic compounds being stored, but also in their utilization.

Ameasurement of digestive gland lipid level is a much better index of nutritional state, somatic growth and reproductive potential than the analysis of phaeopigment stores. Lipid metabolism in the sea scallop is known to play a major role in the annual cycle of gametogenesis. Total lipid content and concentration in the sea scallop digestive gland show a similar seasonal pattern of fluctuation as do carbohydrate reserves in the adductor muscle (Robinson et al. 1981). In the particular inshore sea scallop population previously studied, gametogenesis was initiated in early winter, at a time when lipid and carbohydrate reserves were falling. Gonadal growth occurred concurrently with increases in lipid and carbohydrate reserves. The final stages of gamete maturation took 
place at the expense of both lipid and carbohydrate reserves (Robinson et al. 1981). Since both energy reserves show simultaneous seasonal fluctuations, monitoring one of them (e.g. total lipid content of the digestive gland) is reflective of the overall nutritional state of the organism.

Between-year comparisons of lipid levels, however, can only be useful if samples are taken at the same time of year, on scallops at the same state of gametogenesis. In the present study, all scallops were collected during late gametogenesis, prior to spawning, at a time when lipid stores (as well as carbohydrates) should have been close to their annual minimum values (Thompson 1977, Robinson et al. 1981). Although collections were made at the same time each year, it is unlikely that the inshore scallops were at exactly the same stage of gametogenesis and nutritional state as the offshore scallops (Barber et al. 1988), nor would each population be expected to show the same relative states on the same calendar date from one year to the next. As a result of this asynchrony, the lack of correlation between phaeopigment and either digestive gland weight or lipid content when the data from inshore and offshore scallops are lumped together (as in Fig. 2) and analyzed may appear to be an artifact. However, since lipid and digestive gland weight shows a significant direct relationship when the data from inshore and offshore scallops are combined, and since this relationship is similar for both 1986 and 1987 collections, it is highly probable that all the scallops collected were at a sufficiently similar state of gametogenesis and nutrition to justify the comparisons we have made, and to support our conclusion that phaeopigment concentrations and contents are poor indices of nutritional state.

Both offshore sites (Fippennies Ledge, Jeffreys Ledge) showed similar patterns of digestive gland weight, adductor weight, lipid and phaeopigment stores. Scallops from Fippennies Ledge also showed a similar pattern from one year to the next. Since only one inshore site (Ram Island) was sampled, it is appropriate to question whether this site is representative of inshore scallops in general. A preliminary study was conducted in 1985 in which an inshore scallop population from the Damariscotta River, Maine was compared with a population on Jeffreys Ledge. Although the sample size was small (5 scallops from each population) and the methodologies used for both pigment and lipid analyses were different from those used in the present study, the preliminary data supports the conclusions presented here. Scallops from the Damariscotta River had higher adductor muscle weights, digestive gland weights and lipid contents than the Jeffreys Ledge scallops. In contrast to the results of the present study, phaeopigment content was higher for the inshore scal- lops than the offshore. This overall inconsistent pattern of phaeopigment content is further evidence of the inappropriateness of using stored phaeopigment concentrations as an index of nutritional state.

Phaeophorbide a was the primary chlorophyllous pigment identified in the digestive gland, stomach contents and feces of Placopecten magellanicus, although numerous unidentified peaks were present and low concentrations of phaeophytin a and chlorophyllide $a$ were also found. In contrast, phaeophytin a concentrations 34 to $100 \%$ as high as phaeophorbide a concentrations (median $=58 \%$ ) were measured in fresh fecal pellets of Calanus pacificus using HPLC (Vernet \& Lorenzen 1987), although the authors acknowledge that the high proportion of phaeophytin could be attributed to rapid gut passage due to experimentally high food concentrations. Hawkins et al. (1986) demonstrated, using HPLC, that phaeophorbide a-like pigments were the primary indicators of digestive processes in the mussel Mytilus edulis. The bivalve stomach apparently has a low enough $\mathrm{pH}(\sim 5$ to 6 ; Owen 1974 , Morton 1983) to facilitate the removal of the magnesium ion from the tetrapyrrole ring of the chlorophyll molecule (e.g. the production of phaeophytin a from chlorophyll al, as well as the requisite extracellular esterases for dephytolization (e.g. the production of phaeophorbide a from phaeophytin $a$, and the production of chlorophyllide a from chlorophyll a).

Several investigators have utilized chlorophylls and their degradation products in conjunction with some other marker (e.g. carbon, nitrogen, etc.) to calculate copepod absorption efficiencies during gut passage (Landry et al. 1984, Downs \& Lorenzen 1985). Other investigators (Conover et al. 1986, Lopez et al. 1988) have cautioned, however, that chlorophyll $a$ and its derivatives may be destroyed and absorbed during gut passage in zooplankton. Therefore, chlorophyll a is not converted to phaeophorbide a with $100 \%$ efficiency in the zooplankton gut. In bivalves, the absorption and storage of chlorophyll degradation products have been known for some time (Ansell 1974a, b, Gelder \& Robinson 1980, Robinson et al. 1984). In a recent study, Hawkins et al. (1986) showed that as much as $82 \%$ of the chlorophyll ingested by Mytilus edulis is absorbed during gut passage. The present study provides direct evidence that a variety of chlorophyll degradation products are stored in the digestive gland of a bivalve mollusc. As is the case with zooplankton, $100 \%$ of the chlorophyll ingested by bivalves is not converted to phaeophorbide.

Irrespective of the actual amount of chlorophyll a that is digested and absorbed, the ratios of intestinal to stomach (I/S) and digestive gland to stomach (DG/S) chlorophyll a concentrations (as measured by HPLC) point out marked differences between the inshore and 
offshore scallop populations. These ratios implicate differences in the digestive physiologies of the scallops from these 2 sites as well. In Ram Island scallops for example, intestinal chlorophyll a concentrations are higher than those for the stomach. This finding is not unexpected, since feces are more compact than stomach contents and bivalves are not totally efficient at breaking down algal food (i.e. digestive efficiencies $<100 \%$; Robinson et al. 1984). The lower I/S chlorophyll a ratio for the offshore scallops may indicate that these scallops have higher digestive efficiencies than inshore scallops, and hence make better utilization of their limited supply of available food, as has been shown for the Japanese little neck clam Tapes japonica fed various ration levels (Langton et al. 1977). Correspondingly, the similar or slightly higher DG/S ratios for the offshore scallops may indicate that their absorption efficiencies are either the same or greater than for the inshore scallops.

Chlorophyllous pigments are apparently absorbed by the digestive gland cells in the same relative proportions as present in the stomach and intestinal contents. This is rather surprising in view of the current theory of feeding and digestion in bivalves (Owen 1974, Morton 1983). Large particles enter the stomach and are subjected to a lowered $\mathrm{pH}(\sim 5$ to 6$)$ and extracellular enzymes (e.g. non-specific esterases, carbohydrases, proteases). thereby being broken down into smaller particles $(<5 \mu \mathrm{m}$ diam.). These small particles are phagocytised by the digestive cells of the digestive gland and are further broken down by the enzymes of the lysosomal system. It is generally agreed that the main site of digestion is intracellular, within the vacuoles of the digestive cells. The data presented in this study indicate that this may not be the case, since the lysosomal system apparently does not break down the chlorophyllous pigments any further than they are already broken down in the stomach. Phaeophorbides, chlorophyllides, phaeophytins, etc. are simply absorbed by the digestive cells, and maintained in intracellular vacuoles along with lipids until they are eventually processed. As an alternative explanation, the chlorophyll $a$, chlorophyllide $a$, phaeophytin $a_{f}$ etc. extracted from the digestive gland tissue may represent the newly ingested material that is presently undergoing further lysosomal breakdown to phaeophorbide or other degradation products In either case, a critical examination of the pathways and time course for complete chlorophyll a breakdown within the stomach and digestive cells could provide new insights into the digestive processes of bivalve molluscs.

Acknowledgements. Research was supported by the U.S. National Oceanic and Atmospheric Administration (NOAA) National Undersea Research Program at Avery Point, Univer- sity of Connecticut. Our warmest thanks are extended to Douglas Privitt, Richard Slater, and the rest of the operating crew of the submersible 'Delta', for all their interest and enthusiasm, and for getting us home safely. We also thank the captains and crews of the support vessels 'Atlantic Twin' and 'Powell Our sincerest thanks go to Susan Scott Gibson for cheerful and proficient word-processing. Thanks are also extended to Daniel Schick and Paul Berkman for their useful discussions and assistance during the course of this study.

\section{LITERATURE CITED}

Adams, J. A., Steele, J. H. (1966). Shipboard experiments on the feeding of Calanus finmarchicus (Gunnerus). In: Barnes, $\mathrm{H}$. (ed.) Some contemporary studies in marine science. Allen \& Unwin, London, p. 19-35

Ansell, A. D. (1974a). Seasonal changes in biochemical composition of the bivalve Abra alba from the Clyde Sea area. Mar. Biol. 25: 13-20

Ansell, A. D. (1974b). Seasonal changes in biochemical composition of the bivalve Chlamys septemradiata from the Clyde Sea area. Mar. Biol. 25: 85-99

Baars, M. A., Oosterhuis, S. S. (1984). Diumal feeding rhythms in North Sea copepods measured by gut fluorescence, digestive enzyme activity and grazing on labelled food Neth. J. Sea Res. 18: 97-119

Babinchak, J., Ukeles, R. (1979). Epifluorescence microscopy, a technique for the study of feeding in Crassostrea virginica veliger larvae. Mar. Biol. 51. 69-76

Barber, B. S., Getchell, R., Shumway, S., Schick, D. (1988). Reduced fecundity in a deep-water population of the giant scallop Placopecten magellanicus in the Gulf of Maine. Mar. Ecol. Prog. Ser. 42: 207-212

Bligh, E. G., Dyer, W. J. (1959). A rapid method of total lipid extraction and purification. Can. J. Biochem. Physiol. 37. 911-917

Bricelj, V M., Malouf, R. E. (1984). Influence of algal and suspended sediment concentrations on the feeding physiology of the hard clam Mercenaria mercenaria. Mar. Biol 84: 155-165

Conover. R. J., Durvasula, R., Roy, S., Wang, R. (1986). Probable loss of chlorophyll-derived pigments during passage through the gut of zooplankton, and some of the consequences. Limnol. Oceanogr. 31: 878-887

Dagg, M. J. (1983). A method for the determination of copepod feeding rates during short time intervals. Mar. Biol. 75: 63-67

Downs, J. N., Lorenzen, C. J. (1985). Carbon: phaeopigment ratios of zooplankton fecal pellets as an index of herbivorous feeding. Limnol. Oceanogr 30: 1024-1036

Gelder, S. R., Robinson, W. E. (1980). Identification of phaeopigments in the digestive gland of Mytilus edulis L. by microspectrofluorimetry. J. exp. mar Biol. Ecol. 43: $281-292$

Grossnickle, N. E. (1979). Nocturnal feeding patterns of Mysis relicta in Lake Michigan, based on gut content fluorescence. Lumnol. Oceanogr 24:777-780

Hains, J. J. (1985). Practical considerations for routine chlorophyll measurements: precautions and comparison of extraction methods. J. fresh. Ecol. 3: 175-179

Hawkins, A. J S., Bayne, B. L., Mantoura, R. F. C., Llewellyn, C. A., Navarro, E. (1986). Chlorophyll degradation and absorption throughout the digestive system of the blue mussel Mytilus edulis L. J. exp. mar. Biol. Ecol. 96: $213-223$ 
Head, E. J. H., Wang, R., Conover, R. J. (1984). Comparison of diurnal feeding rhythms in Temora longicornis and Centropages hamatus with digestive enzyme activity. J. Plankton Res. 6: 543-551

Holm-Hansen, O., Lorenzen, C. J., Holmes, R. W., Strickland, J. D. H. (1965). Fluorometric determination of chlorophyll. J. Cons perm. int. Explor Mer 30: 3-15

Hummel, H. (1985). Food intake of Macoma balthica (Mollusca) in relation to seasonal changes in its potential food on a tidal flat in the Dutch Wadden Sea. Neth. J. Sea Res. 19: $52-76$

Landry, M. R., Hassett, R. P., Fagerness, V., Downs, J., Lorenzen, C. J. (1984). Effect of food acclimation on assimilation efficiency of Calanus pacificus. Limnol. Oceanogr 29: 361-364

Langton, R. W., Winter, J. E., Roels, O. A. (1977). The effect of ration size on the growth and growth efficiency of the bivalve mollusc Tapes japonica. Aquaculture 12: 283-292

Le Pennec, M., Rangel-Davalos, C. (1985). Observations en microscopie a epifluorescence de l'ingestion et de la digestion d'algues unicellulaires chez des jeunes larves de Pecten maximus (Pectinidae,Bivalvia). Aquaculture 47 : 39-51

Lopez, M. D. G., Huntley, M. E., Sykes, P. F. (1988). Pigment destruction by Calanus pacificus: impact on the estimation of water column fluxes. J. Plankton Res. 10: 715-734

MacDonald, B. A., Thompson, R. J. (1985). Influence of temperature and food availability on the ecological energetics of the giant scallop Placopecten magellanicus. II. Reproductive output and total production. Mar Ecol. Prog. Ser 25: 295-303

MacDonald, B. A., Thompson, R. J., Bayne, B. L. (1987). Influence of temperature and food availability on the ecological energetics of the giant scallop Placopecten magellanicus. IV Reproductive effort, value and cost. Oecologia (Berl.) 72: 550-556

Mackas, D., Bohrer, R. (1976). Fluorescence analysis of zooplankton gut contents and an investigation of diel feeding patterns. J. exp. mar. Biol. Ecol. 25: 77-85

Mackas, D. L., Burns, K. E. (1986). Poststarvation feeding and swimming activity in Calanus pacificus and Metridia pacifica. Limnol. Oceanogr 31: 383-392

Madin, L. P., Cetta, C. M. (1984). The use of gut fluorescence to estimate grazing by oceanic salps. J. Plankton Res. 6 : 475-492

Mann, R. (1977). An assessment of the use of pigment content as a feeding index in oysters. Aquaculture 10:373-376

Mantoura, R. F. C., Llewellyn, C. A. (1983). The rapid determination of algal chlorophyll and carotenoid pigments and their breakdown products in natural waters by reversephase high-performance liquid chromatography. Analyt. chim. Acta 151: 297-314

Morton, B. S. (1983). Feeding and digestion in Bivalvia. In: Saleuddin, A. S. M., Wilbur, K. M. (eds.) The Mollusca,

This article was presented by Professor K. R. Tenore, Solomons, Maryland, USA
Vol. 5, Physiology, Part 2. Academic Press, New York, p. $65-147$

Ohman, M. D. (1988). Sources of variability in measurements of copepod lipids and gut fluorescence in the California Current coastal zone. Mar. Ecol. Prog. Ser 42: 143-153

Owen, G. (1974). Feeding and digestion in the Bivalvia. Adv comp. Physiol. Biochem. 5: 1-35

Robinson, W E. (1983). Quantification of ingestion by Mercenaria mercenaria (L.) veligers feeding on mixed suspensions of inert material and algae using microspectrofluorimetry. J. moll. Stud., Suppl. 12A: 167-171

Robinson, W. E., Wehling, W. E., Morse, M. P., McLeod, G. C. (1981). Seasonal changes in soft-body component indices and energy reserves in the Atlantic deep-sea scallop, Placopecten magellanicus. Fish. Bull. U.S. 79: 449-458

Robinson, W E., Wehling, W. E., Morse, M. P. (1984). The effect of suspended clay on feeding and digestive efficiency of the surf clam, Spisula solidissima (Dillwyn). J. exp. mar. Biol. Ecol. 74: 1--12

Schick, D. F., Shumway, S. E., Hunter, M. (in press). Allometric relationship and growth in Placopecten magellanicus: the effects of season and depth. Malacol. Rev.

Shumway, S. E., Selvin, R, Schick, D. F. (1987). Food resources related to habitat in the scallop Placopecten magelJanicus (Gmelin, 1791): a qualitative study. J. Shellfish Res. 6: $89-95$

Strickland, J. D. H., Parsons, T R. (1972). A practical handbook of seawater analysis, 2nd edn. Bull. Fish. Res. Bd Can. 167

Thompson, R. J. (1977). Blood chemistry, biochemical composition, and the annual reproductive cycle in the giant scallop, Placopecten magellanicus, from southeast Newfoundland. J. Fish. Res. Bd Can. 34: 2104-2116

Townsend, D. W., Spinrad, R. W. (1986). Early spring phytoplankton blooms in the Gulf of Maine. Cont. Shelf Res. 6: 515-529

Trees, C. C., Kennicutt, M. C. II, Brooks, J. M. (1985). Errors associated with the standard fluorimetric determination of chlorophylls and phaeopigments. Mar Chem. 17: 1-12

Vernet, M., Lorenzen, C. J. (1987). The relative abundance of pheophorbide $a$ and pheophytin $a$ in temperate marine waters. Limnol. Oceanogr. 32: 352-358

Wang, R., Conover, R. J. (1986). Dynamics of gut pigment in the copepod Temora longicornis and the determination of in situ grazing rates. Limnol. Oceanogr. 31. 867-877

Watanabe, T., Mazaki, H., Nakazato, M. (1987). Chlorophyll a/a' epimerization in organic solvents. Biochim. Biophys. Acta 892: 197-206

Watanabe, T., Nakazato, M., Honda, K. (1986). Kinetic and thermodynamic parameters for the pheophytin a/a' epimerization in organic solvents. Chem. Lett. 86: 253-256

Zapata, M., Ayala, A. M., Franco, J. M., Garrido, J. L. (1987). Separation of chlorophylls and their degradation products in marine phytoplankton by reversed-phase high-performance liquid chromatography. Chromatographia 23: 26-30

Manuscript received: May 5, 1988

Revised version accepted: December 15, 1988 